\title{
Molecular Characterization Of Hair Cuticle And Its Extracted Proteins In Seven Mammalian Species
}

\author{
S. K. Areida, M. F. Ismail, E. K. Abdel Hady, and A. O. Osman \\ Zoology Department, Faculty of Science, Mansoura University, Mansoura, Egypt.
}

\begin{abstract}
Hair is an of the epidermis in mammals and consists of two large groups of human hair proteins. One is hard $\alpha$-keratins and the other is matrix proteins. The present investigation aimed to compare the ultrastructural of the hair scale using the scanning electron microscope, and the proteins and amino acids content of the keratin in seven mammalian species.

The values of the hair thickness, $x / y$ feret and hair pattern of the species in the present study confirm the presence of species-specific characteristics and ultra structural variation. The situation in man differs from the wild mammals due to damage of hair cuticle caused by mechanical abuse, exposure to ultraviolet radiation and chemical over processing. The maximum amount of extracted proteins from hair keratin was analyzed by SDS-PAGE. The electrophoretic patterns showed an overall degree of similarity. However, differences exist between species in the intensity of stain. Quantitatively, the electrophoretic patterns scanned and analyzed using gel protein analyzer. The results showed no difference between the molecular mass of some species, but different in molecular mass distribution.
\end{abstract}

Amino acid composition of keratin of mammalian hair species of the present study showed some variation, especially for methionine, isoleucine, lysine and arginine. The other amino acids studied are significantly present in most hair. One of the later amino acid is cysteine. Cysteine is a very important due to the presence of disulfate cross-links.

\section{Introduction}

The molecular structure and chemistry of hair was to be considered in seeking to understand the damaging effects of topically applied preparations (i.e., perming, bleaching, dyeing and shampooing), environmental influences (i.e., sunlight and oxidants), and mechanical factors (i.e., combing, brushing, and drying). The cuticle has been recognized as a tough and impervious layer providing protection for the hair shaft emerging from the follicle. 1,2) Keratinized tissues such as hair have been recognized as useful sources for the studies on structural proteins.

Hair shaft consists of an outer cuticle surrounding a central cortex which may contain a central medulla. The keratin fiber is primarily made up to insoluble keratin intermediate filament (IF) proteins. The inters pace between the keratin (Ifs) is filled with a matrix of keratin associated proteins (e.g. high sulfur proteins, high glycine tyrosine (HGT) proteins, an non-high sulfur/high glycine tyrosine proteins). ${ }^{3,4,5)}$

The protein content in a keratinized structure, including animal hair, nail, horn and feather, is approximately $80 \%$ of the total mass. ${ }^{6,7)}$ Two large groups of human hair proteins are known. One is hard $\alpha$ keratins forming microfibrous intermediate filaments and the other is matrix proteins forming a nonfilamentous matrix as intermediate filaments-associated proteins. The hard a-keratins are further resolved into two subfamilies, consisting of at least 4-9 distinct type I acidic (40-50 kDa) and 46 type II neutral/basic $(55-65 \mathrm{kDa})$ members. ${ }^{8)}$ Matrix proteins are classified into high-sulfur proteins $(10-20 \mathrm{kDa})$ and high-tyrosine proteins $(6-9 \mathrm{kDa}) . \quad \mathrm{N}$ terminal acetylations have been reported for a post-translational modification of animal hair a-keratins and the related proteins.,10) Little is known, however, about 
posttranslational modifications of human hair a-keratins and the related proteins, while epithelial cytokeratins or soft akeratins have been well studied. ${ }^{11)}$

A number of procedures have been reported to isolate hard a-keratins and their related proteins for analyses. ${ }^{12,13)}$ It is difficult to obtain them in the native state, because the hard a keratins are highly crosslinked with each other by disulfide bonds, enabling intermediate filaments to covalently cross link with matrix proteins. Proteins extracted from keratinized structures are generally prepared by reduction in the presence of denaturing agent and S-alkylation under extremely low or high $\mathrm{pH}$ conditions. Using a combination of these reagents, protein yields were not uniform and protein hydrolysis was liable to occur. ${ }^{14) \text {. }}$

The better understanding of the morphological variations of human hairs by SEM. ${ }^{15,16)}$ The scales in the basal portion form mostly a petal pattern that often shifted into a double chevron or an interrupted streaked waved pattern. More distally, they presented a single or double chevron pattern, which is present over the major portion of the shaft. In the apical portion of the wool hairs the double chevron pattern changed progressively into a single chevron and hence into a regular waved pattern with smooth scale margins. The very tip of the wool hair presented a coronal scale pattern with smooth and parallel scale borders. $^{17,18,19,20,21,22,23,24,25)}$ Based on a computer-assisted method and regression analysis, several structural parameters of the hair cuticle pattern of primary hairs of 94 wild mammalian species of seven orders and 44 domesticated mammals of 10 species. Biologically relevant relationships between the parameters examined could only be obtained for the wild animals. In this way domestication-induced defects became evident for the hair cuticula pattern that is a typical structural feature of the hair shaft. ${ }^{26)}$

The diameter of hair shaft measured and scales counted for ten different body sites which enabled them to classify hair into three distinct types: (a) scalp, (b) eyebrow and eyelash, (c) hair from other areas of the body. ${ }^{27,28)}$ More recently, listed six morphological types of hair: (a) head, (b) eyebrow and eyelash, (c) beard and mustache, (d) body hair, (pubic hair, and (f) axillaries hair. ${ }^{29)}$ The keratin fibrils are oriented parallel to the long axis of the hair, and pigment granules are found in and between cells. ${ }^{30)}$

In the present study, The scanning electron microscope has been a superb tool for providing a better understanding of hair morphology. Moreover, more complete, and often more useful data can be obtained by comparing data obtained with scanning electron microscopy and molecular biology of proteins and amino acids of keratins.

\section{Materials And Methods}

\section{Experimental Animals:}

A- Rousettus aegyptiacus (Fruit-eating bats) : The specimens were captured from Abu Rawash near (Giza).

B- Lepus capensis rothschildi (Cape Hare) : The specimens were captured from Southern and Northern region of Eastern and Western Desert.

C- Gerbillus gerbillus (Lesser Egyptian gerbil) : The specimens were captured from Asyout, The Nile Delta and the Western Desert.

D- Pachyuromys duprasi (Rat-tailed gerbil) : The specimens were captured from Natron Valley and Marsa Matrouh.

E- Vulpes vulpes (Red fox) : The specimens were captured from the Nile Valley, the Nile Delta and the Southern part of the Eastern Desert.

F- Felis chaus nilotica (Tungle cat): The specimens were captured from the southern region of the western desert, El-Dakhlah and El-Farafrah Oasis.

G- Homo sapiens (Man): The specimens were collected from some male volunteers.

\section{Extraction of Hair Proteins:}

Mammalian hair was washed with ethanol; external lipids were removed using a mixture of chloroform /methanol $(2: 1, \mathrm{v} / \mathrm{v})$ for $24 \mathrm{~h}$. The delipidized hairs 
(20mg) were extracted with various extraction buffers $(5 \mathrm{ml})$, containing $25 \mathrm{mM}$ Tris-Hcl, $\mathrm{pH} 8.5,2.6 \mathrm{M}$ thiourea, $5 \mathrm{M}$ urea and either $0.2 \mathrm{M}$ 2-mercaptoethanol (2-ME) or dithiothreitol (DTT). The obtained supernatant was filtrated and used as a hair protein fraction. The pellet was recovered, washed with distilled water and used as an extracted hair sample.

Preparation of section for scanning electron microscope (SEM):

Untreated hairs from different types of animals and human were cleaned according to the procedure of Hess ${ }^{31)}$, which consisted of placing hair samples in small dishes of distilled water containing a drop of detergent (Baby Johnson) and sonicating for $5 \mathrm{~min}$. Hairs were then washed in distilled water, sonicated for 5 min. in desiccated acetone, and either air dried, bloted on kimwipes, or blown dry with freon in a duster before being mounted on SEM stubs. All the specimens were gold coated before being examined with a JEOL JXA-840A Electron Probe Microanalyzer Scanning Electron Microscope at $20 \mathrm{kv}$.

\section{Determination of extracted proteins:}

A hair protein fraction was dialyzed against 21 of distilled water with 5-7 changes, lyophilized, and then dried sufficiently in a silicagel box. Alternatively, an extracted hair sample was washed with distilled water and then dried in a silicagel box. The amounts of a hair protein fraction and of an extracted hair sample were obtained by weighing the dried samples using an electronic balance.

\section{Bradford Method:}

Protein amounts were determined by the colorimetric method of Bradford ${ }^{32}$ ) using the Bio-Rad protein assay (Bio-Rad).

\section{SDS Gel Electrophoresis}

SDS gel electrophoresis was done according to the method described by Laemmli ${ }^{33)}$ with some deviation. The gel scanning on a laser densitometer for heightened sensitivity. The scans analysed using associated computer peripherals and gel protein analyzer.

\section{Amino acid analysis of hair keratins:}

The amino acid compositions of extracted proteins of mammalian hairs were determined on amino acid analyzer (Biochrom 20, Amersham Pharmacia Biotech) using post column ninhydrin derivatization. Samples were centrifuged at $3700 \mathrm{x} \mathrm{g}$ for $15 \mathrm{~min}$.. After lyophilization of the samples, hydrolysis were carried out by $6 \mathrm{M} \mathrm{HCL}$ for $24 \mathrm{~h}$ at $110{ }^{\circ} \mathrm{C}$ in the presense of nitrogen. The samples were dried under vaccum, redissolved in 10 to $100 \mu \mathrm{l} 0.2 \mathrm{M}$ sodium citrate buffer, $\mathrm{pH} 2.0$, and loaded on the amino acid analyzer equipped with a certain exchange column(Amersham Pharmacia Biotech), wich was equilibrated in $0.2 \mathrm{M}$ sodium citrate buffer, $\mathrm{pH}$ 2.0. Elution was performed with a gradient of $\mathrm{pH}$ and ionic strength as instructed by the manufacturer.

\section{Results}

\section{1-Scanning electron microscopic observations:}

\section{A) Rosuettus agyptiacus:}

Fruit-eating bats (Rosuettus agyptiacus), which are belonging to family Pteropodidae, have somewhat straight scalp hair. The thickness of these hairs differs according to the region of the hair. The top region is about $17.3 \mu \mathrm{m}$ in thickness. However, the middle and basal regions are about $19.1 \mu \mathrm{m}$ and $22.6 \mu \mathrm{m}$, respectively (Table 1, and fig.1). The ratio of scale width and height $(X / Y$ feret) also differ according to the region of hair. The top region is about 1.0. However, the middle and basal regions are bout 1.5 and 1.2 respectively (Table 2). Moreover, the scale category in the three regions are similar which is coronal with unequal hastate and smooth margin (Table 2) and (fig. 2).

\section{B) Lepus capensis rothschildi:}

Cape Hare (Lepus capensis rothschildi), which is belonging to family Leporidae, has somewhat straight scalp hair. The top region is about $18 \mu \mathrm{m}$ in thickness. However, the middle and basal regions are about $26.2 \mu \mathrm{m}$ and $47.1 \mu \mathrm{m}$ 
respectively (Table 1 , and fig.1). The ratio of scale width $(X / Y$ feret) of the top region is about 2.6. While, the middle and basal region are about 2.5 and 10.5 respectively (Table 2). Moreover, the scale category in the three regions is similar which is imbricate with equal hastate and smooth margin (Table 2) and (fig. 2).

\section{C) Gerbillus gerbillus:}

Lesser Egyptian gerbil (Gerbillus gerbillus), which is belonging to family Cricetidae, has somewhat straight scalp hair. The thickness of top region is about 27.7, while, the middle and basal regions are about $51.1 \mu \mathrm{m}$ and $62.4 \mu \mathrm{m}$ respectively (Table 1, and fig. 1). The ratio of scale width and height $(X / Y$ feret) of top region is about 3.3. However, the middle and basal regions are about 4.2 and 4.8 respectively (Table 2). Moreover, the scale category in the three regions are similar which his coronal with equal hastate and smooth margin (Table 2) and (fig. 2).

\section{D) Pachyuromys duprasi:}

Rat-tailed gerbil (Pachyuromys duprasi), which is also belonging to family Cricetidae, has somewhat straight scalp hair. The thickness of top region is about $20.6 \mu \mathrm{m}$. However, the middle and basal regions are about $29.3 \mu \mathrm{m}$ and $37.5 \mu \mathrm{m}$ respectively (Table 1 , and fig.1). The ratio of scale width and height $(X / Y$ feret) of top region is about 1.6. While, the middle and basal regions are about 0.5 and 1.4 respectively (Table 2 ). Moreover, the scale category in the three regions is similar which is imbricate with unequal hastate and smooth margin (Table 2) and (fig. 3).

\section{E) Vulpes vulpes:}

Red fox (Vulpes vulpes), which is belonging to family Canidae, has thickness of hairs differ according to the region of these hairs. The top region is about $22.2 \mu \mathrm{m}$ in thickness. However, the middle and basal regions are about $37.1 \mu \mathrm{m}$ and $46.6 \mu \mathrm{m}$ respectively (Table 1 , and fig.1). The ratio of scale $(X / Y$ feret) of top region is about 1.2. While, the middle and basal regions are about 1.4 and 1.1 respectively (Table 2 ). Moreover, the scale category in the three regions is mostly similar which is imbricate with unequal hastate and saw margin at the top region only but smooth margin at the middle and basal regions (Table 2) and (fig. $3)$.

\section{F) Felis chaus nilotica:}

Jungle cat (Felis chaus nilotica), which is belonging to family Felidae, has somewhat straight scalp hair. The thickness of these hairs differ according tot eh region of the hair. The top region is about $12.6 \mu \mathrm{m}$ in thickness. However, the middle and basal regions are about $15.3 \mu \mathrm{m}$ and $22.8 \mu \mathrm{m}$ respectively (Table 1 , and fig.1). The ratio of scale width and height $(X / Y$ feret) also differ according to the region of hair. The top region is about 2.1. However, the middle and basal regions are about 1.3 and 4.1 respectively (Table 2 ). Moreover, the scale category in the three regions is similar which is coronal with equal hastate and smooth margin (Table 2) and (fig. 3).

\section{G) Homo sapiens:}

Man (Homo sapiens) who is belonging to family Hominidae has somewhat straight scalp hair. The thickness of hairs of top region is about $30.8 \mu \mathrm{m}$, and the middle and basal regions are about 35.7 $\mu \mathrm{m}$ and $65.1 \mu \mathrm{m}$ respectively (Table 1 , and fig.1). This hair shaft is ultra structurally with intact tightly overlapping cuticular scale. The outside surface of these scales is imbricated. They are arranged like shingle on a roof with smooth homogenous and shiny surface. The ratio of scale width and height $(X / Y$ feret) also differ according to the region of hair. The top region is about 3.8. However, the middle and basal regions are about 2.9 and 6.8 respectively (Table 2 ). Moreover, the scale category in the three regions is similar which is imbricate with equal hastate and saw margin (Table 2) and (fig. 3).

2- Effects of time, temperature and
reductant on the protein extraction from
different mammalian hair:
In order to obtain the maximum amount of extracted protein using in investigation, the extraction of different mammalian hair protein was performed at 


\section{S. K. Areida et al}

various conditions as time, temperature and reductant. The obtained amounts of extracted protein were very high in case of using reducing agents either with dithiothreitol (DTT) or with $\beta$ mercaptoethanol (ME) (Fig. 4 and 5). While, in the absence of reducing agents, only about $5-10 \%$ protein was extracted (Fig. 4 and 5). As well as, the effective extraction conditions as time and temperature increase the extracted protein amounts in the different species of mammalian hairs. The optimal amount of extracted protein was obtained at $50^{\circ} \mathrm{C}$ after 72 hours of incubation in buffers containing DTT or ME, as shown in (Fig. 4 and 5; table 3). Therefore, the optimal conditions of time, temperature, and reductant, are necessary to obtained high extracted protein from different mammalian hair. On the other hand, the amounts of extracted protein were very low under short time, low temperature and nonreducing conditions. The extraction either at $37^{\circ} \mathrm{C}$ for 24,48 and 72 hours or at $50^{\circ} \mathrm{C}$ for 24 and 48 hours of incubation produced low protein content (data not show). These results indicate that the optimal conditions for extraction were when mammalian hairs were incubated at $50^{\circ} \mathrm{C}$ for $72 \mathrm{hrs}$ in the presence of reducing agent (DTT), as shown in (Fig. 4 and 5).

\section{3- A comparative electrophoretic patterns of extracted protein from different mammalian hair:}

The extracted proteins were analyzed by SDS-PAGE under reducing and nonreducing conditions for the investigation of the keratin structure in different mammalian hair. The protein fractions extracted under DTT were composed of micro-fibril keratins with a molecular mass of (55-65 $\mathrm{kDa}),(40-50 \mathrm{kDa})$ and matrix protein with a molecular mass of (10-15 kDa) and (15$25 \mathrm{kDa}$ ) (Fig. 7). While, the protein fractions produced under ME were composed of two high molecular weight components (about 50-60 kDa and 40-50 $\mathrm{kDa}$ ) and two low molecular mass of 25-35 $\mathrm{kDa}$ and 10-20 kDa (Fig. 6). These observations indicate that the presence of DTT or ME in the extraction buffers cause an effective dissociation between keratin proteins and keratin associated proteins as shown by the electrophoretic patterns with Coomassie Brilliant blue stain (Fig. 6).

Although the SDS-PAGE-patterns showed an overall degree of similarity, clear differences exist between species in the intensity of stain, some protein bands, and the molecular mass distribution of the major zones. Interspecific differences are illustrated in fig. 6. Protein patterns under ME reductant of Homo sapiens, Vulpes vulpes, Pachyuromys duprasi, and Lepus capensis show protein bands with molecular mass of $(25-35 \mathrm{kDa})$. The protein patterns of all species under DTT or ME reductants showed similarity in bands with molecular mass of (55-65 kDa) and (40-50 kDa) (Fig. 6 and 7).

To compare between keratin polypeptide bands in all mammalian species quantitatively, the electrophoretic patterns were analyzed. The Coomassie stained gels scanned and analyzed using laser densitometer gel protein analyzer. Analysis showed two sharp peaks around the molecular mass of the (10-20 kDa) and (15$35 \mathrm{kDa}$ ) respectively (Fig. 8 and 9). These peaks are similar in molecular weight in all species but completely different in the intensity of stain and the molecular mass distribution of the major zones (fig. 6). As shown in figure (6), all mammalian species showed a characteristic pattern recognizably different from each other especially in the two peaks around (40-50 kDa) and $(50-60 \mathrm{kDa})$. These results indicate no differences were observed between the apparent molecular mass of some mammalian species, but the different in intensity of stain and molecular mass distribution in electrophoretic patterns of some mammalian species (Fig. 8 and 9).

\section{4- Amino acid composition of the extracted proteins from mammalian hair:}

In order to compare between mammalian hair species, the extracted protein were analyzed on an amino acid analyzer. The obtained data determined 17 amino acids. The hair of mammalian 
species showed a wide variation in amino acid composition (table 4).

Most of the amino acids composition of Rousettus aegyptiacus are significantly different from those of other animals studied except for histidine and lysine (Table 4). Also, most of the amino acids composition of Lepus capensis are significantly different from those of other animals studied except for lysine, and isoleucine (Table 4). Moreover, most of the amino acid composition of Gerbillus gerbillus are significantly different from those of other animals studied except for lysine (Table 4). On the other hand, Pachyuromys duprasi are significantly different from those of other animals studied except for lysine, cysteine, serine, and alanine .In addition, most of the amino acid composition of Vulpes vulpes are significantly different from those of other animals studied except for isoleucine, tyrosine, phenylalanine, and aspartic acid (Table 4). Most of the amino acids composition of Felis chaus are significantly different from those of other animals studied except for tyrosine, and lysine (Table 4). The most striking feature of Homo sapiens is the significant difference of all the amino acid composition in the hair from those of other animals studied except for lysine which is not significant (Table 4).

From the above observations it has been found that the level of lysine content is the only amino acid that is not significantly present in all mammalian hair, while the other amino acids are significantly present in mammalian hair (Table 4).

Fig. (1): The thickness of hair in different mammals used in the present study.

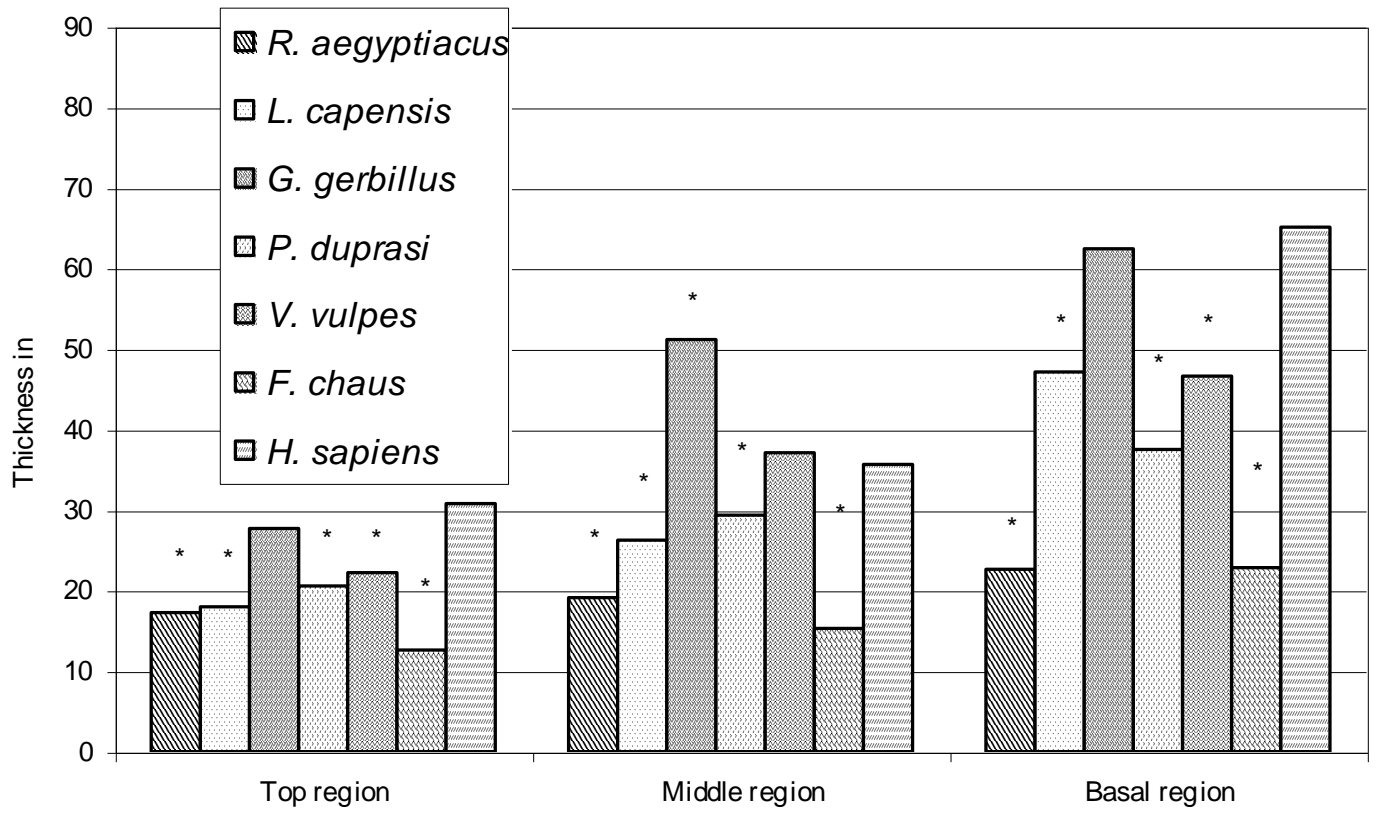


Table (1):The thickness of hair in different mammals used in the present study.

\begin{tabular}{|c|c|c|c|c|}
\hline & & Top region & Middle region & Basal region \\
\hline \multirow{3}{*}{ 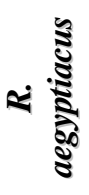 } & $\bar{X}$ & 17.3 & 19.1 & 22.6 \\
\hline & SD & 1.527 & 0.866 & 1.121 \\
\hline & SE & 0.683 & 0.387 & 0.501 \\
\hline \multirow{3}{*}{ 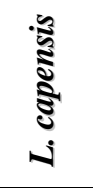 } & $\overline{\mathrm{X}}$ & 18 & 26.2 & 47.1 \\
\hline & SD & 3.413 & 4.254 & 0.538 \\
\hline & SE & 1.526 & 1.902 & 0.240 \\
\hline \multirow{3}{*}{ ن } & $\bar{X}$ & 27.7 & 51.1 & 62.4 \\
\hline & SD & 0.695 & 2.23 & 0.823 \\
\hline & SE & 0.311 & 0.997 & 0.368 \\
\hline \multirow{3}{*}{ 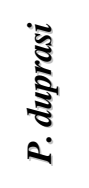 } & $\bar{X}$ & 20.6 & 29.3 & 37.5 \\
\hline & SD & 0.538 & 0.587 & 0.823 \\
\hline & SE & 0.24 & 0.262 & 0.368 \\
\hline \multirow{3}{*}{ 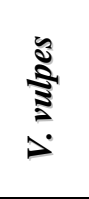 } & $\bar{X}$ & 22.2 & 37.1 & 46.6 \\
\hline & SD & 0.983 & 0.538 & 0.983 \\
\hline & SE & 0.44 & 0.24 & 0.44 \\
\hline \multirow{3}{*}{ 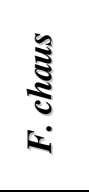 } & $\bar{X}$ & 12.6 & 15.3 & 22.8 \\
\hline & SD & 0.88 & 2.941 & 1.492 \\
\hline & SE & 0.393 & 1.315 & 0.667 \\
\hline \multirow{3}{*}{ 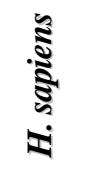 } & $\bar{X}$ & 30.8 & 35.7 & 65.1 \\
\hline & SD & 0.44 & 0.823 & 0.538 \\
\hline & SE & 0.196 & 0.368 & 0.24 \\
\hline
\end{tabular}

* Significant difference 
Table (2): The $X / Y$ feret and scale pattern of the regions hair of mammals

\begin{tabular}{|c|c|c|c|c|}
\hline & $\begin{array}{c}\text { Top } \\
\text { region }\end{array}$ & $\begin{array}{l}\text { Middle } \\
\text { region }\end{array}$ & Basal region & Scale pattern \\
\hline \multirow{2}{*}{ R. aegyptiacus } & \multirow{2}{*}{1.0} & \multirow{2}{*}{1.5} & \multirow{2}{*}{1.2} & Coronal \\
\hline & & & & Unequal hastate with saw margin \\
\hline \multirow{2}{*}{ L. capensis } & \multirow{2}{*}{2.6} & \multirow{2}{*}{2.5} & \multirow{2}{*}{10.5} & Imbricate \\
\hline & & & & Equal hastate with smooth margin \\
\hline \multirow{2}{*}{ G. gerbillus } & \multirow{2}{*}{3.3} & \multirow{2}{*}{4.2} & \multirow{2}{*}{4.8} & Coronal \\
\hline & & & & Equal hastate with smooth margin \\
\hline \multirow{2}{*}{ P. duprasi } & \multirow{2}{*}{1.6} & \multirow{2}{*}{0.5} & \multirow{2}{*}{1.4} & Imbricate \\
\hline & & & & Unequal hastate with smooth margin \\
\hline \multirow[b]{2}{*}{ V. vulpes } & \multirow[b]{2}{*}{1.2} & \multirow[b]{2}{*}{1.4} & \multirow[b]{2}{*}{1.1} & $\begin{array}{l}\text { Imbricate } \\
\end{array}$ \\
\hline & & & & $\begin{array}{l}\text { Unequal hastate with saw margin at the top region only but } \\
\text { smooth at the middle and basal region }\end{array}$ \\
\hline \multirow{2}{*}{ F.chaus } & \multirow{2}{*}{2.1} & \multirow{2}{*}{1.3} & \multirow{2}{*}{4.1} & $\begin{array}{c}\text { Coronal } \\
\end{array}$ \\
\hline & & & & Equal hastate with smooth margin \\
\hline \multirow{2}{*}{ H. sapiens } & \multirow{2}{*}{3.8} & \multirow{2}{*}{2.9} & \multirow{2}{*}{6.8} & Imbricate \\
\hline & & & & Equal hastate with saw margin \\
\hline
\end{tabular}

Width/height $(X / Y$ feret $)$ 
Fig. (2): Scanning electron microscopic of the top region (I), middle region (II), and basal region (III) of a scalp hair shaft in different mammals used in the present study. Note the thickness of hair shaft, overlapped long, and wide scale of the coronal category of unequal hastate with saw margin and without long free blade. (X1000).

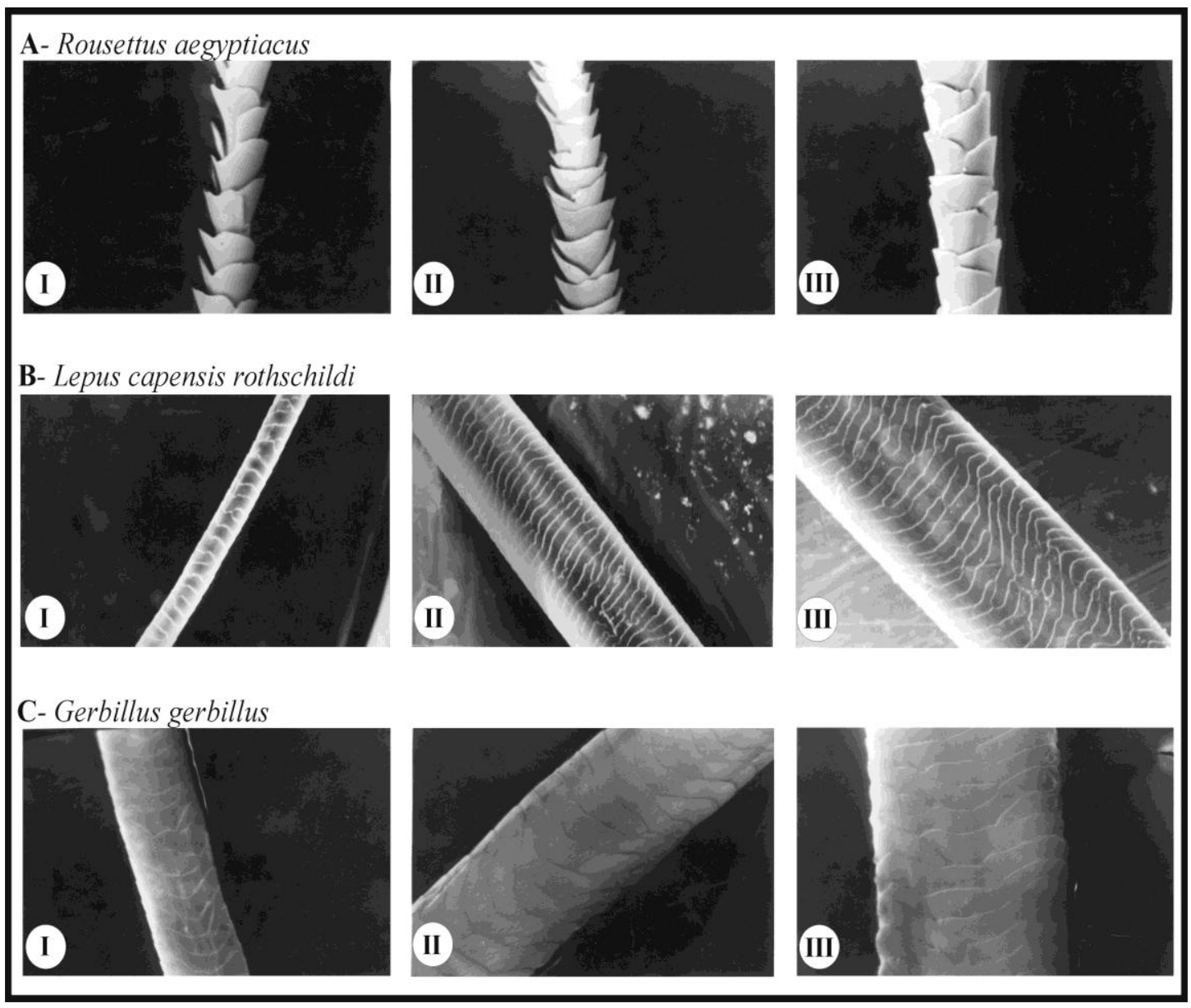


Fig. (3): Scanning electron microscopic of the top region (I), middle region (II), and basal region (III) of a scalp hair shaft in different mammals used in the present study. Note the thickness of hair shaft, overlapped long, and wide scale of the coronal category of unequal hastate with saw margin and without long free blade. (X1000).

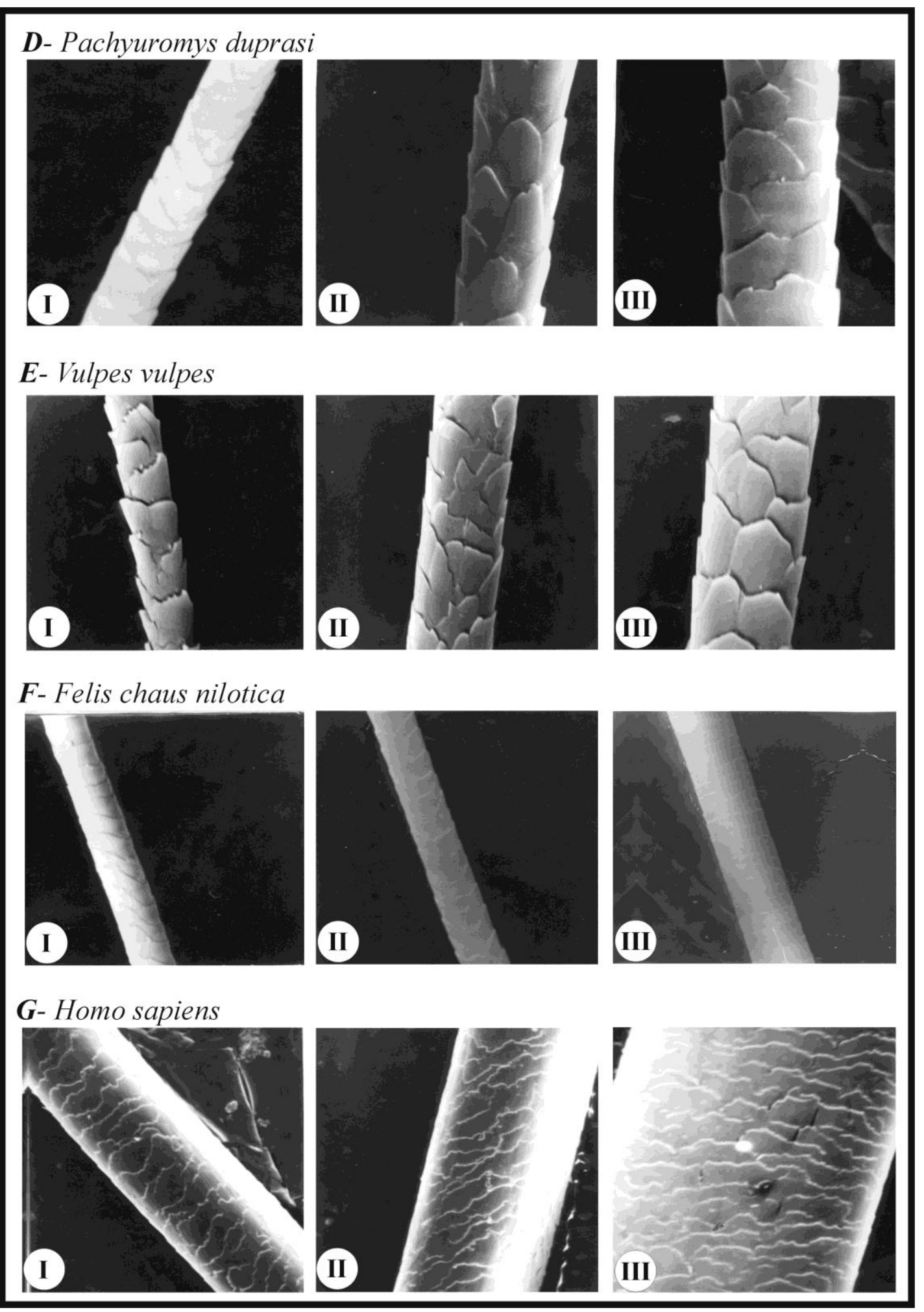


Fig. (4): The time course of extracted protein from human hair at $50^{\circ} \mathrm{C}$ under various conditions.

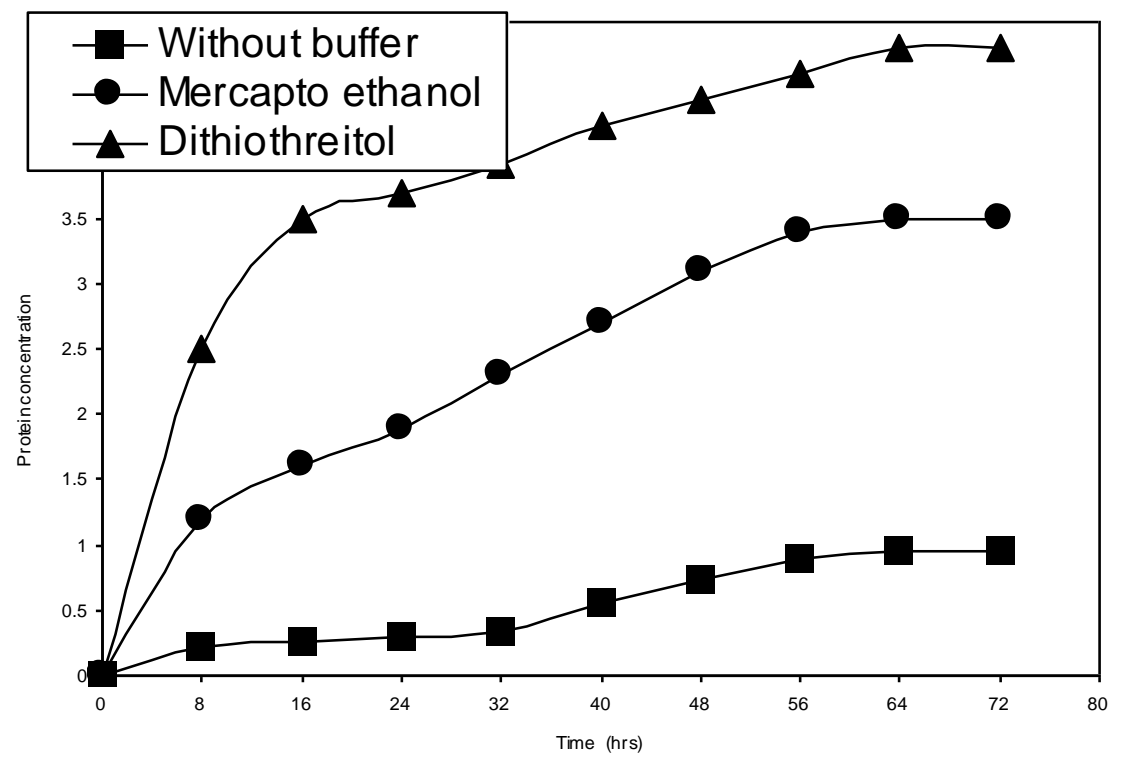

Fig. (5): Total protein content $(\mathrm{mg} / \mathrm{ml})$ of different mammalian hairs at $50^{\circ} \mathrm{C}$ after 72 hours of incubation.

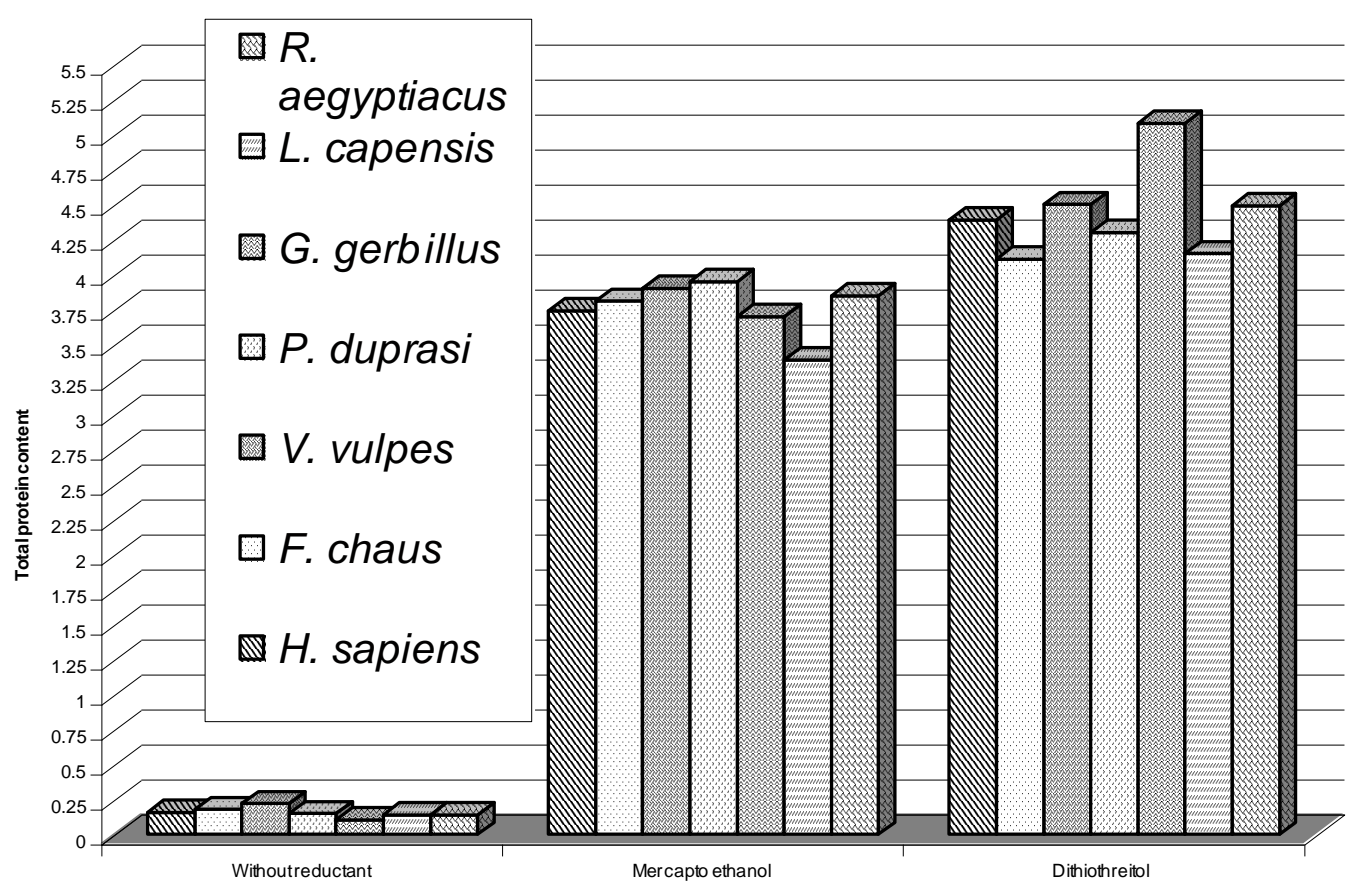


Table (3): Amount of extracted Protein from different mammalian hairs at $50^{\circ} \mathrm{C}$ after 72 hours of incubation with mercaptoethanol (ME), and dithiothreitol (DTT).

\begin{tabular}{|c|c|c|c|c|c|c|c|c|}
\hline & & H. sapiens & F. chaus & V. vulpes & P. duprasi & G. gerbillus & L. capensis & R. aegyptiacus \\
\hline 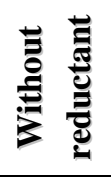 & $\begin{array}{l}X \pm \\
\text { S.E. }\end{array}$ & $\begin{array}{c}0.139 \pm \\
0.003\end{array}$ & $\begin{array}{l}0.14 \pm \\
0.015\end{array}$ & $\begin{array}{c}0.105 \pm \\
0.002\end{array}$ & $\begin{array}{c}0.148 \pm \\
0.001\end{array}$ & $\begin{array}{c}0.22 \pm \\
0.007\end{array}$ & $\begin{array}{c}0.178 \pm \\
0.003\end{array}$ & $\begin{array}{c}0.179 \pm \\
0.003\end{array}$ \\
\hline$\sum_{\Sigma}^{5}$ & $\begin{array}{l}X \pm \\
\text { S.E. }\end{array}$ & $\begin{array}{l}3.85 \pm \\
0.035\end{array}$ & $\begin{array}{l}3.39 \pm \\
0.031\end{array}$ & $\begin{array}{l}3.7 \pm \\
0.114\end{array}$ & $\begin{array}{l}3.95 \pm \\
0.017\end{array}$ & $\begin{array}{l}3.9 \pm \\
0.130\end{array}$ & $\begin{array}{l}3.81 \pm \\
0.013\end{array}$ & $\begin{array}{l}3.59 \pm \\
0.014\end{array}$ \\
\hline 它 & $\begin{array}{l}X \pm \\
\text { S.E. }\end{array}$ & $\begin{array}{l}4.49 \pm \\
0.068\end{array}$ & $\begin{array}{l}4.15 \pm \\
0.036\end{array}$ & $\begin{array}{l}5.08 \pm \\
0.029\end{array}$ & $\begin{array}{l}4.3 \pm \\
0.065\end{array}$ & $\begin{array}{l}4.5 \pm \\
0.170\end{array}$ & $\begin{array}{l}4.11 \pm \\
0.031\end{array}$ & $\begin{array}{l}4.15 \pm \\
0.017\end{array}$ \\
\hline
\end{tabular}

Fig. (6):SDS-PAGE patterns of protein extracts from different mammalian hairs under ME reductant. From the left, Homo sapiens (1), Felis chaus (2), Vulpes vulpes (3), Pachyuromys duprasi (4), Gerbillus gerbillus (5), Lepus capensis (6) and Rousettus aegyptiacus (7).

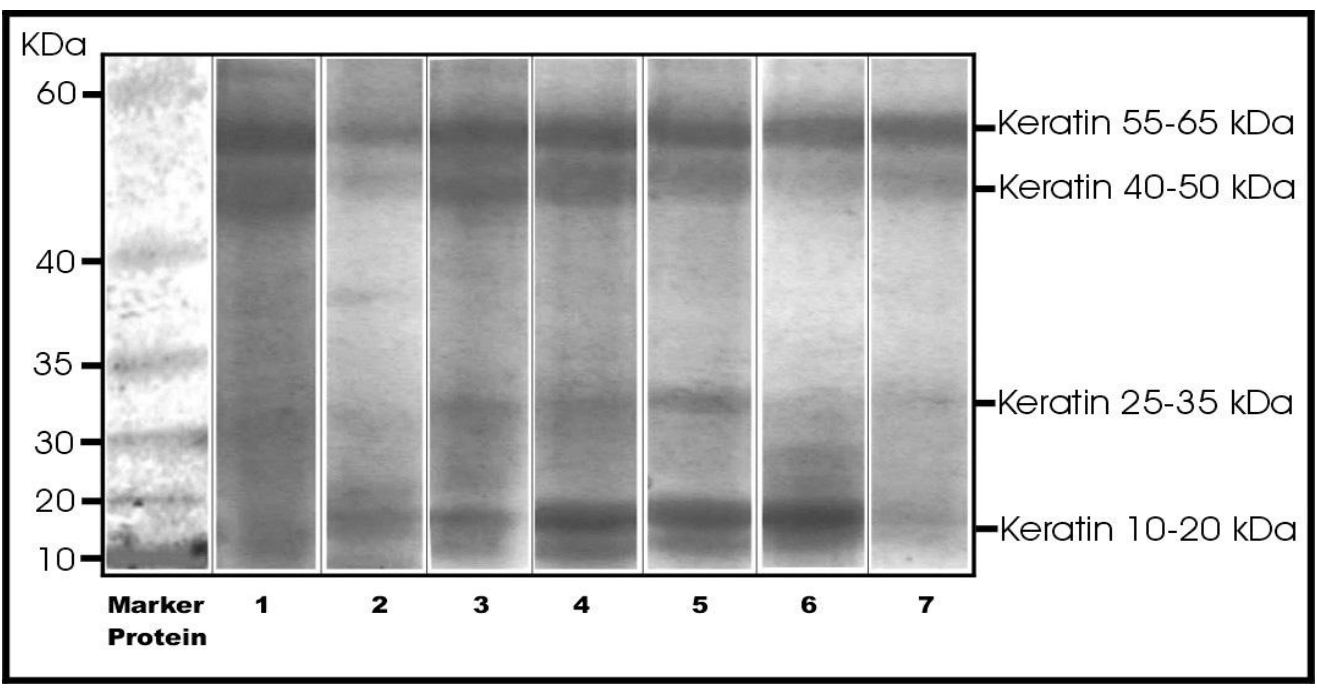


Fig. (7):SDS-PAGE patterns of protein extracts from different mammalian hairs under DTT reductant. From the left, Homo sapiens (1), Felis chaus (2), Vulpes vulpes (3), Pachyuromys duprasi (4), Gerbillus gerbillus (5), Lepus capensis (6) and Rousettus aegyptiacus (7).

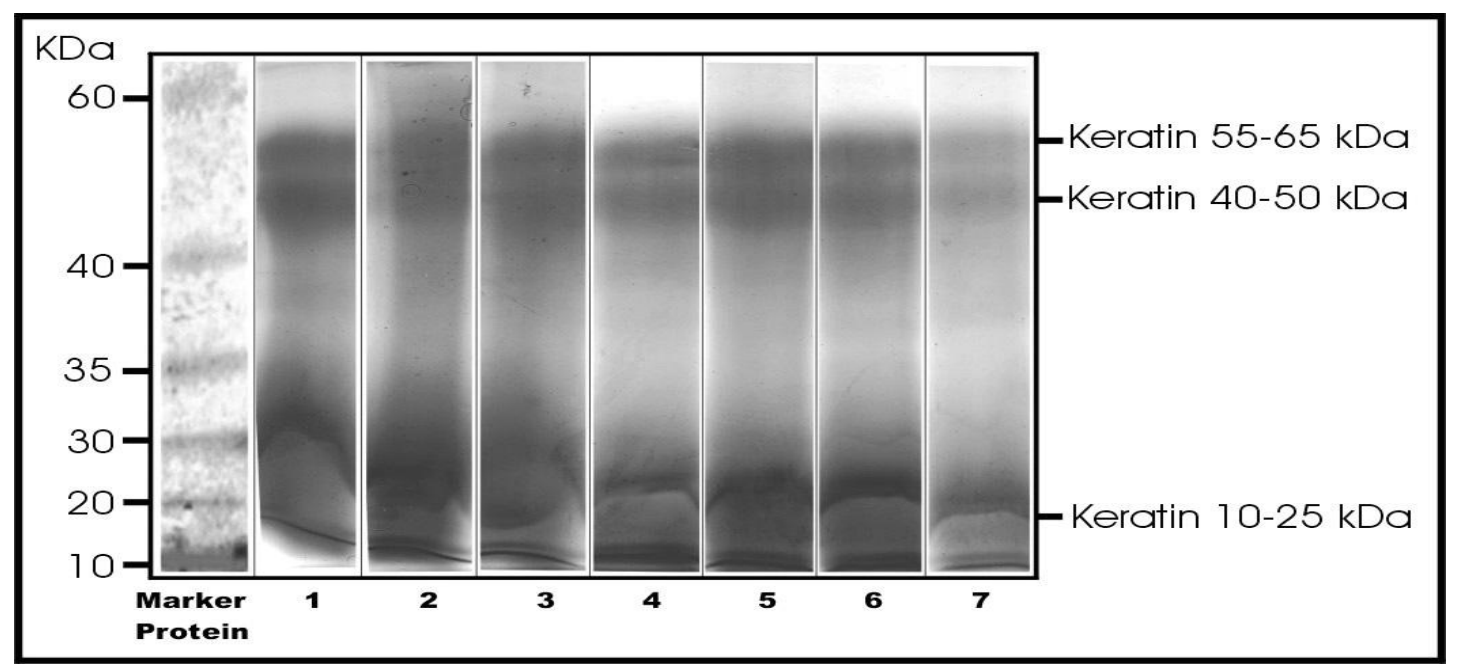

Fig. (8):Profile of Laser densitometer traces of SDS-PAGE gel of keratin patterns of different mammalian hairs. (i) Densitometer profile of protein gel stained with Coomassie Blue under ME reductant. (ii) Densitometer profile of protein gel stained with Coomassie Blue under DDT reductant.

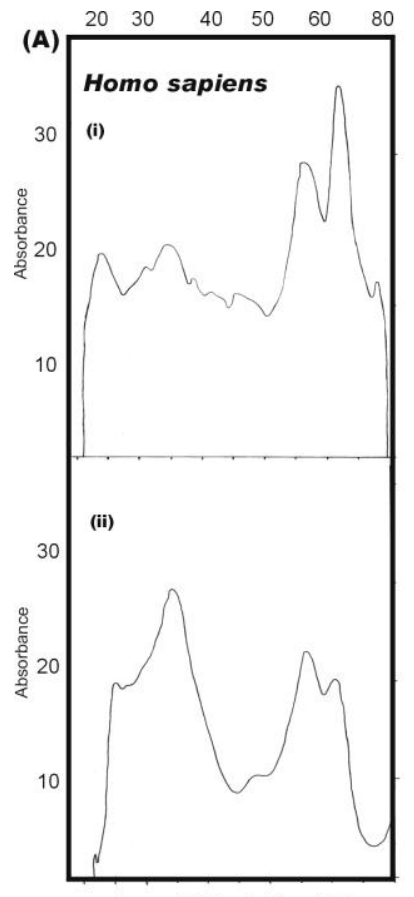

Apparent Molecular Mass (KDa)

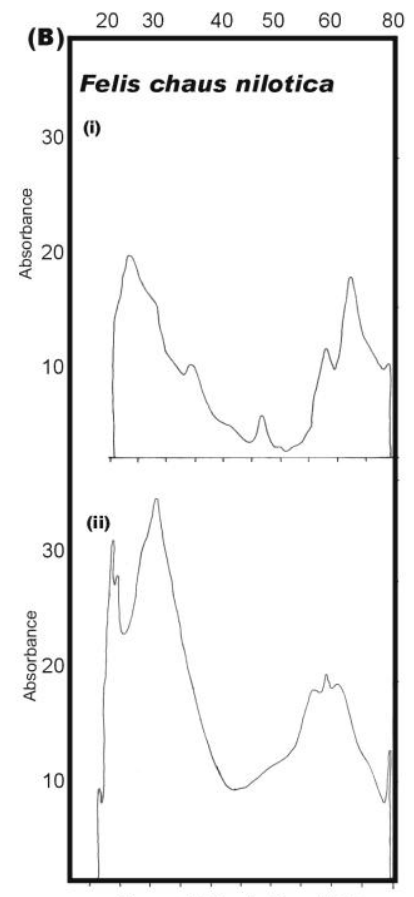

Apparent Molecular Mass (kDa)

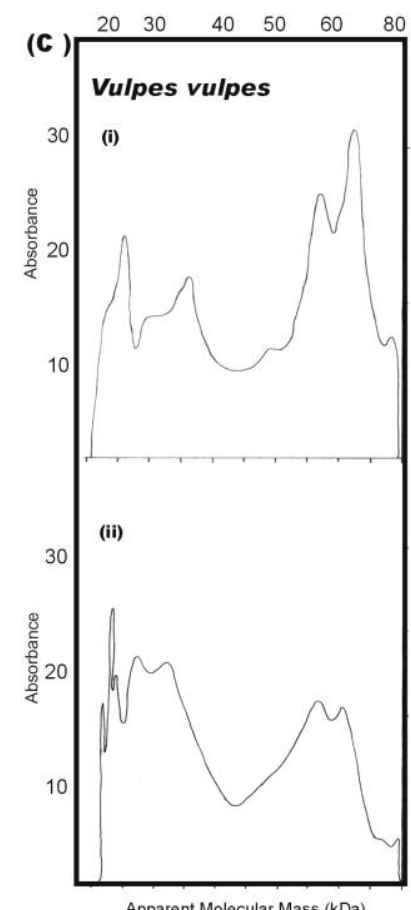

Apparent Molecular Mass (KDa) 
Fig. (9):Profile of Laser densitometer traces of SDS-PAGE gel of keratin patterns of different mammalian hairs. (i) Densitometer profile of protein gel stained with Coomassie Blue under ME reductant. (ii) Densitometer profile of protein gel stained with Coomassie Blue under DDT reductant.

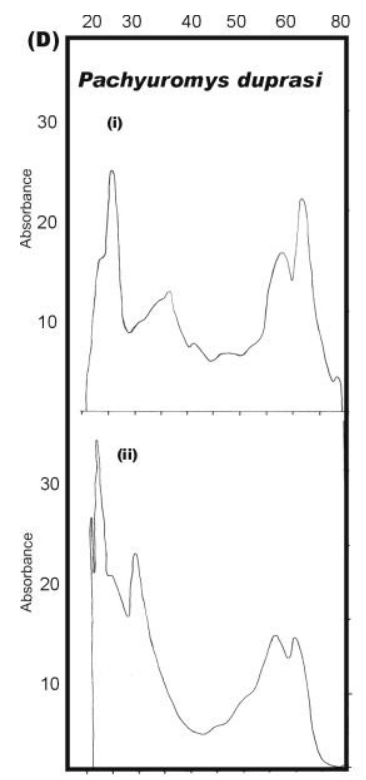

Apparent Molecular Mass $(\mathrm{kDa})$

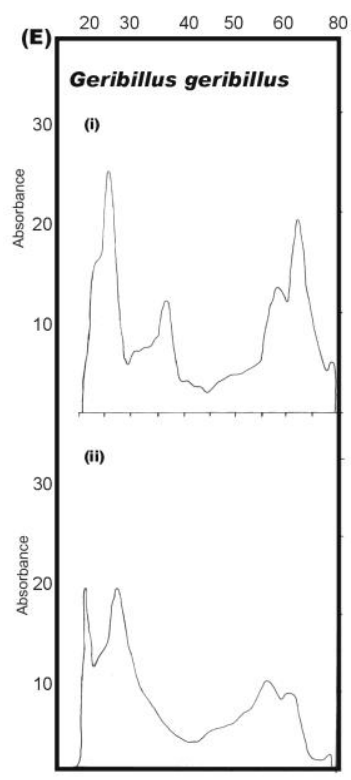

Apparent Molecular Mass (kDa)

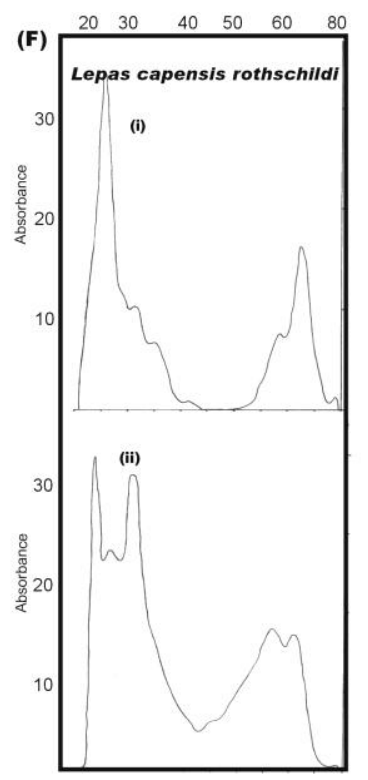

Apparent Molecular Mass (kDa)

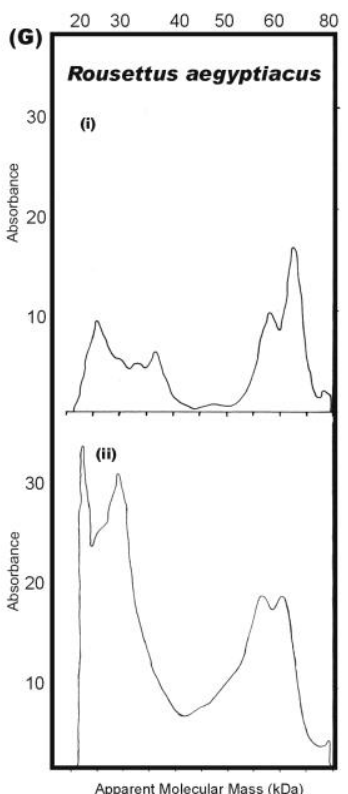


Table (4): Relative composition of essential and nonessential amino acids in different mammalian hair species ( $\square \mathrm{M} / \mathrm{g}$ ).

\begin{tabular}{|c|c|c|c|c|c|c|c|}
\hline Amino & H. sapiens & F. chaus & V. vulpes & P. duprasi & G. gerbillus & L. capensis & R. aegyptiacus \\
\hline \multirow{2}{*}{ Threonine } & 79.61 & $70.76 *$ & $76.43 *$ & $61.85 *$ & $58.50 *$ & $61.85 *$ & $71.16 *$ \\
\hline & \pm 0.319 & \pm 0.325 & \pm 0.322 & \pm 0.328 & \pm 0.333 & \pm 0.328 & \pm 0.332 \\
\hline \multirow{2}{*}{ Valine } & 70.95 & $66.32 *$ & $67.27 *$ & $63.01 *$ & $63.67 *$ & $66.47 *$ & $88.20 *$ \\
\hline & \pm 0.322 & \pm 0.322 & \pm 0.323 & \pm 0.320 & \pm 0.323 & \pm 0.332 & \pm 0.328 \\
\hline \multirow{2}{*}{ Methionine } & 5.96 & $9.82 *$ & $11.47 *$ & $9.64 *$ & $9.33 *$ & $8.93 *$ & $8.75 *$ \\
\hline & \pm 0.319 & \pm 0.319 & \pm 0.322 & \pm 0.325 & \pm 0.324 & \pm 0.322 & \pm 0.325 \\
\hline \multirow{2}{*}{ Isoleucine } & 36.13 & $30.34 *$ & 34.14 & $34.68 *$ & $38.75 *$ & 34.72 & $30.02 *$ \\
\hline & \pm 0.322 & \pm 0.325 & \pm 0.325 & \pm 0.335 & \pm 0.325 & \pm 0.328 & \pm 0.322 \\
\hline \multirow{2}{*}{ Leucine } & 99.16 & $85.39 *$ & $85.25 *$ & $81.4 *$ & $88.37 *$ & $92.29 *$ & $81.26 *$ \\
\hline & \pm 0.325 & \pm 0.335 & \pm 0.328 & \pm 0.325 & \pm 0.332 & \pm 0.328 & \pm 0.325 \\
\hline \multirow{2}{*}{ Tyrosine } & 24.37 & 22.92 & 24.5 & $39.23 *$ & $42.16 *$ & $34.57 *$ & $19.52 *$ \\
\hline & \pm 0.332 & \pm 0.322 & \pm 0.332 & \pm 0.325 & \pm 0.325 & \pm 0.335 & \pm 0.319 \\
\hline \multirow{2}{*}{ Phenylalanine } & 19.76 & $23.68 *$ & 20.20 & $25.98 *$ & $27.39 *$ & $26.46 *$ & $16.81 *$ \\
\hline & \pm 0.319 & \pm 0.335 & \pm 0.325 & \pm 0.325 & \pm 0.329 & \pm 0.332 & \pm 0.325 \\
\hline \multirow{2}{*}{ Histidine } & 12 & $20.29 *$ & $14.88 *$ & $15.57 *$ & $17.46 *$ & $22.5 *$ & 11.13 \\
\hline & \pm 0.320 & \pm 0.328 & \pm 0.326 & \pm 0.335 & \pm 0.332 & \pm 0.338 & \pm 0.322 \\
\hline \multirow{2}{*}{ Lysine } & 11.4 & 11.74 & $13.01 *$ & 11.2 & 12.49 & 11.7 & 10.95 \\
\hline & \pm 0.326 & \pm 0.322 & \pm 0.320 & \pm 0.330 & \pm 0.332 & \pm 0.329 & \pm 0.329 \\
\hline \multirow{2}{*}{ Arginine } & 76.15 & $69.04 *$ & $68.28 *$ & $69.17 *$ & $68.53 *$ & $71.19 *$ & $58.78 *$ \\
\hline & \pm 0.329 & \pm 0.328 & \pm 0.335 & \pm 0.332 & \pm 0.322 & \pm 0.335 & \pm 0.335 \\
\hline \multirow{2}{*}{ Cysteine } & 1310 & $1110 *$ & $1002 *$ & 1316 & $1206 *$ & $809 *$ & $990 *$ \\
\hline & \pm 3.535 & \pm 3.535 & \pm 0.707 & \pm 0.707 & \pm 2.121 & \pm 1.303 & \pm 1.702 \\
\hline \multirow{2}{*}{ Aspartic acid } & 79.59 & $81.74 *$ & 78.15 & $76.35 *$ & $82.23 *$ & $77.37 *$ & $68.51 *$ \\
\hline & \pm 0.327 & \pm 0.338 & \pm 0.335 & \pm 0.311 & \pm 0.324 & \pm 0.326 & \pm 0.327 \\
\hline \multirow{2}{*}{ Serine } & 116.74 & $118.85 *$ & $120.03 *$ & 115.83 & $103.6 *$ & $103.64 *$ & $128.17 *$ \\
\hline & \pm 0.325 & \pm 0.328 & \pm 0.325 & \pm 0.322 & \pm 0.332 & \pm 0.326 & \pm 0.335 \\
\hline \multirow{2}{*}{ Proline } & 73.4 & $66.45 *$ & $76.41 *$ & $70.38 *$ & $60.7 *$ & $67.11 *$ & $90.66 *$ \\
\hline & \pm 0.341 & \pm 0.322 & \pm 0.325 & \pm 0.326 & \pm 0.332 & \pm 0.335 & \pm 0.322 \\
\hline \multirow{2}{*}{ Glutamine } & 176.4 & $151.9 *$ & $159.53 *$ & $160.61 *$ & $163.17 *$ & $162.38 *$ & $143.2 *$ \\
\hline & \pm 0.338 & \pm 0.322 & \pm 0.325 & \pm 0.322 & \pm 0.322 & \pm 0.332 & \pm 0.329 \\
\hline \multirow{2}{*}{ Glycine } & 63.58 & $105.62 *$ & $83.71 *$ & $104.82 *$ & $99.82 *$ & $93.93 *$ & $99.33 *$ \\
\hline & \pm 0.335 & \pm 0.328 & \pm 0.332 & \pm 0.325 & \pm 0.332 & \pm 0.325 & \pm 0.322 \\
\hline \multirow{2}{*}{ Alanine } & 60.03 & $65.15 *$ & $66.63 *$ & 60.26 & $63.82 *$ & $64.9 *$ & $73.55 *$ \\
\hline & \pm 0.326 & \pm 0.329 & \pm 0.322 & \pm 0.328 & \pm 0.319 & \pm 0.326 & \pm 0.328 \\
\hline
\end{tabular}

The data represented as mean \pm S.E.

$*$ = significant difference 


\section{Discussion}

\section{Scanning electron microscopic observations of mammalian hairs}

Characterization of hair cuticle, as well as, its extracted proteins, retained in the keratinized tissues is important to advance our understanding of keratinization in mammalian hairs. In this study, The scales of mammalian hair were analyzed by ultrastructural using SEM. More information was obtained from the examination of mammalian hair keratins by SDS-PAGE and amino acid analysis.

The ratio of scale width to height could reflect an effective function for the cuticle scales in supporting (i.e. holding up) the thin hairs. These scales form a segmented tube that can support the rather thin hair cortex when the hairs are erect during cold periods in order to improve insulation. The hair cuticle cells have an extremely keratinized outer core, which corroborate this idea, and they are very resistant to mechanical deformation. ${ }^{34,35}$ ) These aspects are of minor importance in large mammals in which the hair cortex is rather thick. ${ }^{36,37)}$ In the present material small mammals have thin hair and small $x / y$ feret except in Gerbillus, which has thick hair and large $x / y$ feret. This might be due to the habitat of this animal, which accommodates itself during cold periods. It lives in the desert in order to improve insulation. The structural analysis of the hair cuticle pattern can help to reveal certain basic zoosystematical relationships between and within different mammalian groups.

The specific scale structure reported in five vespertilionid species (insect-eating bats) could generally be explained as a help to increase flight efficiently by influencing the airflow over the body, creating a turbulent boundary layer to aid hovering and gliding flight, for example. ${ }^{36)}$ Similar mechanisms are known from lobated scales on lepidopteron wings (Butterflies and moths) as stated by Nachtigall ${ }^{38)}$, or from the feather structure and arrangement on the wings of birds. ${ }^{39,40,41)}$ In general, adaptive significance in hair structure of bats-as strongly denied by Nason ${ }^{42)}$ and Benedict
43) obviously exists in this mammalian group. Nevertheless, a comparative evaluation of possible contributions of physical attributes of bat hairs to adaptations as, for example, related to thermoregulation, ectoparasitism, physical attachments, or feeding activities is still lacking. ${ }^{44,45)}$ However, the close relationship of scaledependent parameters with coat density in Chiroptera and small Rodentia may indirectly indicate the evolution of a light and homogenous hair coat with high insulation qualities. This idea is partly corroborated by the view that for effective thermoregulation the uniformity of hair coat thickness seems to be more important than the maximal thickness of the hair coat at certain body region. ${ }^{46}$ ) This is particularly the case for animals with small body volume, because homogeneity of the hair types or the hair coat obviously implies a better insulation, which is necessary in these mammals because of their relatively large body surface. ${ }^{26)}$

The ratio of scale width to scale height clearly indicates that the speciesspecific shape and size of hair cuticle scales in mammals may be of specific value for biological interpretation with regard to hair coat structures and function. This seems to be generally true for the larger families of the order carnivora - the Canidae like fox and the Felidae like cat. ${ }^{37)}$ In the present study the $x / y$ feret and the scale pattern of cat and fox are completely different.

The illustrated findings of the present study confirm and complement previous descriptions of the hair patterns that are found in rabbits and are relevant for different fields of research. Microanatomical data of cover hairs are useful for studies in wildlife biology and ecology. ${ }^{47,48)}$ Whereas the wool fibres of rabbits have been studied in detail because of their economic value in the textile industry. ${ }^{22,24,49}$ ) The study of Broeck ${ }^{25)}$ confirms the presence of speciesspecific characteristics as well as individual and breed-dependent variations of the structural hair components in rabbits. The present study showed that the $\mathrm{x} / \mathrm{y}$ feret and scale pattern of rabbit have a different style. 


\section{S. K. Areida et al}

Extraction of mammalian hair was done in various reducing conditions. The amounts of extracted protein were low under the non reducing conditions, whereas approximately $70 \%$ of the hair weight was obtained in the presence of reducing agents. The effective extraction conditions as time and temperature increase the extracted protein amount in all mammalian hairs. Therefore, the three conditions, time, temperature and reductant, are necessary for extraction of protein of mammalian hair.

A number of procedures have been reported that to isolate hard $\alpha$-keratins and their related proteins for analyses. ${ }^{52,53)}$ It is difficult to obtain them in the native state, because the hard $\alpha$-keratins are highly cross-linked with each other by disulphide bonds, enabling intermediate filaments to covalently cross-link with matrix proteins. Proteins extracted from keratinized structure of mammalian hairs in the present study are generally prepared by reduction in the presence of DTT or ME as well as optimal time and temperature. These results are in agreement with data from a rapid extraction procedure of human hair proteins. ${ }^{53,54)}$

\section{A comparative electrophoretic pattern of mammalian hairs:}

More information can be obtained from the examination of mammalian hair keratins by SDS-PAGE. In the present study, the extracted proteins were fractionated into many bands with different in the molecular masses. These bands contain many of microfibril keratins with a molecular mass of 50-60- kDa, 40-50 kDa and matrix with molecular masses of 10-15 and $15-25 \mathrm{kDa}$. The protein bands produced under DTT or ME reductants have composed of both homologous and heterologous proteins.

The electrophoretic patterns of the present investigation showed clear differences in some bands of mammalian hairs indicating that the keratins contain different proteins either homologous or heterologous.

The protein fractions of the high sulphur type are electrophoretically heterogeneous. Indeed, sufficient differences exist between the mobilities of compon- ents even within the one species to provide a means of distinguishing for example, the wool proteins of one breed of sheep from another breed. ${ }^{55)}$ In the present study the improved electrophoretic resolution has allowed the separation of a substantial number of components from the hairs of many different animals. Clearly, the present results yield heterogeneity and homogeneity protein, which showed completely, differences in the intensity of coomassie blue stain and the molecular mass distribution of the major zones of different keratin bands. These results were supported by Woods and Orwin ${ }^{56)}$ and O'Donnell ${ }^{57)}$ who observed that electrophoretic patterns of SCM-proteins, which have bee, extracted from the $\beta$-keratins of bird feathers and beak have a simple structure. However, that of wool is more comlicated.

The $\alpha$-keratins showed heterogeneity of different proteins, which were not shown by $\beta$-keratins. Electrophoretic pattern spans almost the same distance on the gel, indicating that keratins are a set of homologous proteins, which cover approximately the same range of size and charge.

Many of the differences noted between different species dealed with the relative quantity of a certain polypeptide rather than with the presence or absence of the polypeptide.

In the present study, differences in the intensity of the polypeptide bands were detected in SDS-PAGE although the same quantity of protein was loaded on the gels for each sample.

A difference may exist in the rate of biosynthesis of major keratin polypeptides. It must be remembered that keratins are heteropolymers in which at least one member of each subfamily is always coexpressed in any given epithelial tissue. Furthermore, a pair of keratins coexpressed in other epithelium. ${ }^{58)}$

In the present study it is evident from the SDS-PAGE profiles, that each type of mammalian hair showed a charateristic reproducible protein pattern. In the meantime some intragroup similarities between the protein patterns can be detected. ${ }^{59)}$ The results of the present 
investigation are in agreement with birds, chicken and duck which showed very similar in electrophoretic patter of extracted relations. ${ }^{60,61)}$

\section{Amino acid composition in mammalian} hairs:

The results obtained by amino acid analysis showed that there is a significant content of cysteine amino acid residue in all-mammalian hairs in compare with other amino acids. Keratins are generally rich in cysteine residues but one of the most striking features of these proteins is their heterogeneity. ${ }^{62}$ The most conventionally studied amino acids of keratins are their Scarboxymethylated derivatives. ${ }^{4}$ The keratins in this study contained proteins as high cysteine proteins.

Similar results were obtained by Gillespie ${ }^{4)}$ and Khawar ${ }^{59)}$ who reported that human hair proteins contain high cysteine protein. The great stability of human hair and its insolubility are caused by the large number of disulfide cross-links between and within the hair protein. As well as, cysteine residues provide stability of the hair as it is not exposed to reducing, oxidizing and hydrolytic agents. ${ }^{63)}$

The pattern of reactivity of hair is complex because it depends not only on the presence of reactive moieties in the fibre but also on their availability. The pattern is significantly affected by fibre morphology and molecular structure. The bulk of hair is proteinaceous in nature with the structural lipids and other materials representing only a minor fraction..

The macromolecular structure of keratin derives its stability from a variety of intra-chain and inter-chain interaction holding the protein chain together. The interactions range from covalent bench, coulombic interaction (salt links), van der waals interaction, and in the presence of water, hydrophobic bands. ${ }^{64)}$

In our study, the amino acid composition of most species are significantly different as histidine, arginine, methionine, isoleucine phenylalanine., tryptophane, valine. . Other studies have, however, repeated similar or lower level contents of amino acid than in whole body values. ${ }^{65,66)}$ Protein composition was apparently distinct from the whole protein extracts, suggesting that soluble proteins might selectively collect into the partial extracts. Nail extract contains both hard Keratin and Cytokeratin, of which solubilities are very different. ${ }^{67)}$

The present results showed that the extracted proteins of all studied mammalian animals contained several and different amino acid composition and these sharing in protein bands of IF Keratins. Keratin associated proteins have been thought to form the rigid hair shaft by cross-linking keratin Ifs. ${ }^{2)}$

In conclusion, It could be concluded that the present study showed some variations in the external feature of the hair cuticle and the proteins and amino acids content of the keratin in seven mammalian species. This could be a better determination of mammalian species and/or groups according to their hair structure.

\section{References}

1) Wolfram, L. J. and Lindemann, M. O. (1971): Some observations on the hair cuticle. J. Soc. Cosmet. Cbem., 22: 839850.

2) Inoue, T.; Ito, M. and Kizawa, K. (2001):: Characterization of eluted proteins form hair fibre under permanent waving or bleaching. J. Soc. Cosmet. Chem. Jap., 35 (3): 237 - 241

3) Powell, B. C. and Rogers, G. E. Jolles, P.; Zhan, H. and Höcker, H. (1997): The role of the keratin proteins and their genes in the growth, structure and properties of hair. Briskhäuser Verlag, Basel, pp. $59-148$

4) Gillespie, J. M. (1991): The structural proteins of hair: Isolation, characterization, and regulation of biosynthesis. Oxford University Press, New York, pp. 625-659

5) Corden, L.D. and Mclean, W. H. I. (2001).: Keratins and keratin disorders molecular and medical aspects of the keratin intermediate filament protein family. In: cell adhesion and migration in skin disease. London: Harwood Academic Publications, pp. 27 - 55

6) Gillespie J. M. (1983): "Biochemistry and Physiology of the Skin I," ed. By Goldsmith L. A., Oxford University Press, London, pp. 475-510 
7) Rogers G. E. (1985): Genes for hair and avian keratins. Ann. N.Y. Acad. Sci., 455, 403-425

8) Heid H. W., Werner E., Franke W. W. (1986): The complement of native alphakeratin polypeptides of hair-forming cells. Differentiation, 32, 101-119

9) Langbein L., Rogers M. A., Winter H., Praetzel S., Beckhaus U., Rackwitz H. R., Schweizer J. (1999).: The catalog of human hair keratins. I. Expression of the nine type I members in the hair follicle. J. Biol. Chem., 274, 1987419884

10) Langbein L., Rogers M. A., Winter H, Praetzel S., Schweizer J. (2001): The catalog of human hair keratins. II. Expression of the six type II members in the hair follicle and the combined catalog of human type I and II keratins. J.Biol. Chem., 276, 35123-35132

11) Haylett T., Swart L. S., Parris D. (1971): Biochemical variation of hair keratins in man and non-human primates. Biochem. J., 123, 191-200

12) Liao J., Ku N. O., Omary M. B. (1996): Two- dimentional gel analysis of glandular keratin intermediate filament phosphory-lation. Electrophoresis, 17, $1671-1676$

13) Corfield M. C., Robson A.: Skinner B. (1958): The amino acid compositions of three fractions from oxidized wool. Biochem. J., 68, 348-352

14) Marshall R. C., Gillespie J. M. (1982): Electrophoretic analysis of non-human primates hair keratin. J. Forensic Sci. Soc., 22, 377-385

15) Bottoms, E. V. A.; Wyatt, E. and Comaish, S. (1972): Progressive changes in cuticular pattern along the shafts of human hair as seen by scanning electron microscopy. Brit. J. Dermatol., 86: $379-384$

16) Hess, W. M.; Seegmiller, R. E.; Gardner, J. S.; Allen, J. V. and Barendregt, S. (1990).: Human hair morphology: A scanning electron microscopy study on a male Caucasoid and a computerized classification of regional differences. $J$. V.: J.Mamm., 4 (2): $375-386$

17) Wildman, A. B. (1954).: The microscopy of animal textile fibres. Wool Industries Research Association, Leeds

18) Rougeot, J. and Thébault, R. G. (1979).: Le poil du lapin Angora. Cuniculture, 6: $169-173$
19) Langley, K. D. and Kennedy, T. A. (1981):: The identification of speciality fibres. Textile Res. J., 51: 703 - 709

20) Latzke, P. M. and Hesse, R. (1988).: Textile Fasern. Rasterelekscher Fachverlag Gmbh, Frankfurt

21) Wortmann, F-J; Wortmann, G. and Arns, W. (1989).: Quantitative fibre mixture analysis by scanning electron microscopy. Textile Res. J., 59: $73-80$

22) Cheng, J. d. and Huang, D. P. J. (1992).: A study on the texture of rabbit wool. In: Proceedings of the $\mathrm{V}$ worlds rabbit congress. Applied Rabbit Res., 15: 1629 $-1632$

23) Schlolaut, W., Angorawolle. In (1995).: Schlolaut W., Lange K., Löhle, K. Löliger Ch. and Rudolph W. (eds.) Das grosse Buch Vom Kaninchen. DLGVerlag, Frankfurt am Main, pp. $33-47$

24) Herrmann, S. Lange, K. and Wortmann, F-J. (1996a): characteristics of Angora rabbit fibre. 2. The influence of the methionine content in feed and of the environmental temperature on fibre and medulla diameter in Angora wool. World Rabbit Sci., 4: 155 - 158

25) Broeck, W. V.; Mortier, P. and Simoens, P. (2001).: Scanning electron microscopic study of different hair types in various breeds of rabbits. Folia Morphol., 60 (1): $33-40$

26) Meyer, W.; Schnapper, A.; Hülmann, G. and Seger, H. (2000).: Subgroup differentiation in the cervidae by hair cuticle analysis. J. Anim. Breed. Genet., 117: $281-283$

27) Wyatt, E. H. and Riggott, J. M. (1977): Scanning electron microscopy of hair; observations on surface morphology with respect to site, sex and age in man. British J. Dermatol., 96: 627 - 633

28) Riggott, J. M. and Wyat, E. H. (1983).: Mensuration of scanning micrographs. A possible means of hair identification. $J$. Forensic Sci. Soc., 23: 155 - 160

29) Valkovic, V. (1988).: Human hair. Fundamentals and methods for measurement of elemental composition. CRC Press, Inc. Boca Raton, Florida, 1: 164

30) Thomas, S. Leeson; Roland, C., .(1981) Leeson and Anthony, A. Paparo

31) Hess, W. M., Flinders, J. T., Pritchett, C. L. and Allen (1985). Characterization of hair morphology in families layassuidae and suidae with scanning electron microscopy. J. V., J.Mamm., 66: 75-84 
32) Bradford M. M. (1976).: A rapid and sensitive method for the quantification of microgram quantities of protein utilizing the principle of protein-dye binding. Anal. Biochem., 72, 248-254

33) Laemmli, U. K. (1970): Cleavage of Structural Proteins During the Assembly of the Head of Bacteriophage T4. Nature, 227 (25): 680-685

34) Dobb, M. G. , Johnston, F. R., Nott, J. A., Oster, l., Sikorski, J. and Simpson, W. S. (1961) : Morphology of the cuticle layer in wool fibres and other animal hairs. J. Text. Inst., 52: 153-170

35) Jones, L. N., Horr, T. J. and Kaplin, I. J., (1994): Formation of surface membranes in developing mammalin hair fibres. Micron, 25: 589-595

36) Meyer, W.; Seger, H. and Hlmann, G. (1995):Remarks on specific adaptive scale structure of the hair cuticle in some European bats. Eur. J. Mrphol., 33: 509 $-513$

37) Meyer, W., Pohlmeyer, K., Schnapper, A. and Hülmann, G., Z. (2001).: Domestication-related variations of the hair cuticula pattern in mammals. Jagdwiss, 47: 253-258

38) Nachtigall,W.,Z. (1967): Aerodynamische Messungen am Tragflügelsystem segelnder Schmetterlinge.. Vergl. Physiol., 54: 210-231

39) Hertel, H. (1963). Struktur- From- Bewegung. Biologie und Technik. Krausskopf, Mainz

40) Nachtigall, W., Kempf, B., (1971). Vergleichende Untersuchungen Zur Flugbiologischen Funktion des Daumenfittichs (Alula Spuria)

41) Rüppell, G., Vogelflug. (1971). Kindler, München

42) Nasson, E. S. (1948).: Morphology of hair of eastern North American bats. Amer. Midl. Natur., 39: 345-361

43) Benedict, F. A. (1957).: Hair structure as a generic character in bats. Univ. Calif. Univ. Calif. Publ. Zool., 59: 285 - 547

44) Quay, W. B. (1970): Integument and derivatives. In: "Biology of Bats". Vol. III (Wa Wimsatt, Ed.), pp. 1 - 56. Academic Press, New York, London

45) Kunz, T. H. (1982).: Ecology of bats. Plenum Press, New York, London

46) Korhonen, H. and Harri, M., Z. (1986).: Comparison of hair coat structure between the raccoon dog and blue fox. Säugetierkd, 51: 281-288
47) Teerink, B. J. (1991).: Hair of westEuropean mammals. Cambridge Univ. Press., Cambridge

48) Wolfe, A. and Long, A. M. (1997).: Distinguishing between the hair fibres of the rabbit and the mountain hare in scats of the red fox. J. Zool., 242: 370-375

49) Herrmann,S.; Wortmann, G. and Wortmann, F.J. (1996b).: characteristics of Angora rabbit fibre.The influence of fibre origin on fibre and medulla diameter in Angora wool. World Rabbit Sci., 4: 149 - 153

50) Lee, W. S., (1999) Proceedings of the international symposium on electron microscopy in medicine and biology. 180-183.

51) Hrdy, D. and Baden H. P. (1973).: Biochemical variation of hair keratins in man and non-human primates. Am. J. Phys. Anthrop. , 39: 19-24

52) Liao, J., Ku, N. O. and Omary, M. B. (1996).: Two- dimentional gel analysis of glandular keratin intermediate filament phosphorylation. Electrophoresis, 17: 1671-1676

53) Nakamura, A., Arimoto, M., Takeuchi, K. (2002), and Fujii, T., Biol. Pharm. Bull., 25(5): 569-572

54) Marshall, T. and Williams, K. M. (1986).: Phenol addition to the Bradford dye binding assay improves sensitivity and gives a characteristic response with different proteins. J. Biochem. Biophys.Methods, 13(3): 145-150

55) Gillespie, J. M. and Inglis, A. S. (1965): Biochemistry and Physiology of the Skin. Comp. Biochem. Physiol., 15: 175-185

56) Woods, J. L. and Orwin D. F. G. (1987).: Wool proteins of New Zealand Romney sheep. Aust. J. Biol. Sci., 40: 1-14

57) O'Donnell I. J. (1973).: The complete amino acid sequence of a feather keratin from emu (Dromaius novae-hollandiea). Aust. J. Biol. Sci., 26: 415-437

58) Steinert, P. M. and Roop, D. R. (1988).: Molecular and cellular biology of intermediate filaments. Anna. Rev. Biochem., 57: 593 - 625

59) Khawar, S. L.; Watson, K. and Jones, G. L. (1995).: High resolution one - dimensional electrophoretic separation and partial characterization of human head hair. Electrophoresis, 16 (1): 110 - 115

60) Presland, R. B., Gregg, K ., Molloy, P. L., Philip Morris C.,Crocker, C.A. and Rogers, G. C. (1989): Avian keratin 
genes-1. A molecular analysis of the structure and expression of a group of feather keratin genes. J. Mol. Biol., 209: 549-559.

61) Marshall, R. C., (1985).In proceedings of the International Symposium on Forensic Hair Comparisons, 71-87.

62) U. S. Government Printing Office, Washington, D. CDarskus, R. L. (1972): Electrophoretic and chromatographic characterization of sulphur rich proteins from wool. J. Chromatogr., 69, $341-348$

63) Zahn, H. and Gattner, H. G., (1997). Hair sulphur amino acid analysis. Exs., 78: $239-58$

64) Wolfram, U. (1981).: The reactivity of human hair. In: Hair research. Orfanos, Montagna, Stuttgen, editors. Berlin Heidelberg: Springer-Verlag, p. 4790

65) Bikker, P.; Verstegen, M. W., and Bosch, M. W. J. (1994).: Amino acid composition of growing pigs is affected by protein and energy intake. Nutr., 124 (10) :1961 - 9

66) Hahn, J. D. and Baker, D. H(1995)..: Optimum ratio to lysine of threonine, tryptophan, and sulphur amino acids for finishing swine. J. Anim. Sci.,73 (2): 482 $-9$

67) Kitahara, T. and Ogawa, H. (1991).: The extraction and characterization of human nail keratin. J. Dermatol. Sci., 2 (6): 402 $-6$ 


\section{الخصائص الجزيئية لجليا الثعر و بروتيناته المستخلصة في بعض الثذييات المصرية بروينة}

\section{السيد كامل عريضهـــ محمد فتحى إسماعيلـ- السيد قاسم عبد الهادىــ اميرة

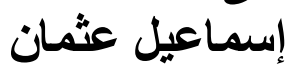

قسم علم الحيوان- كلية العلوم- جامعة المنصورة

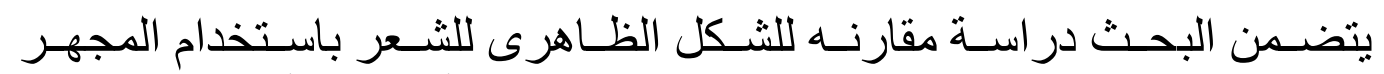

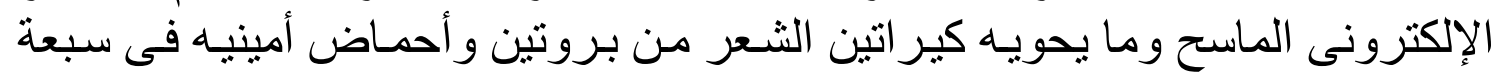

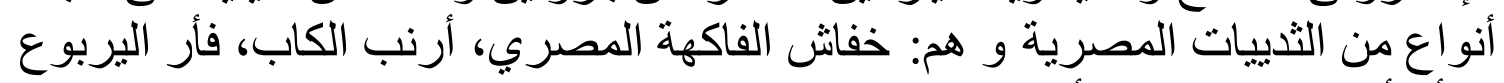

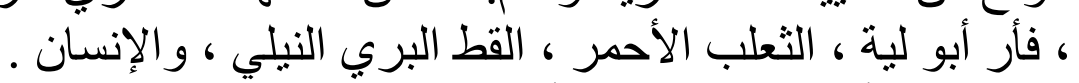

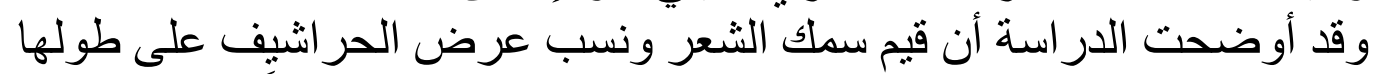

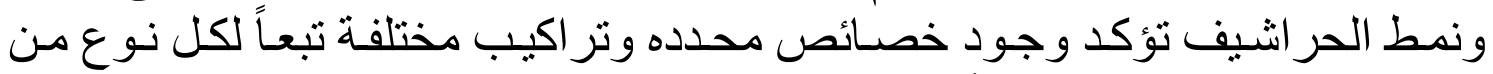

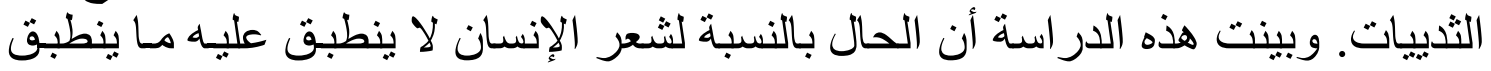

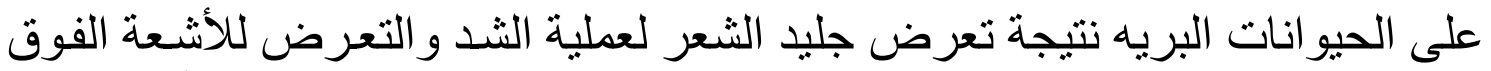

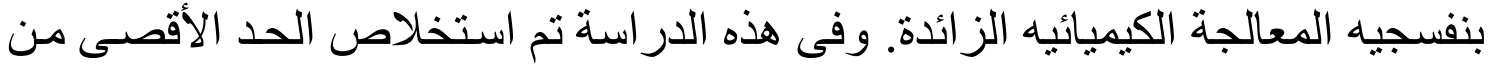

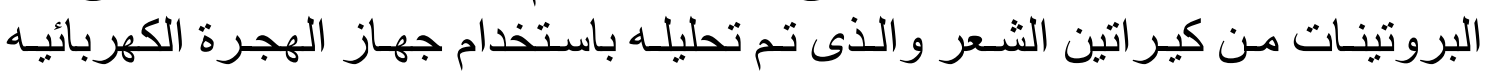

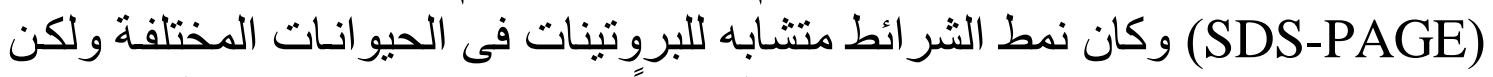

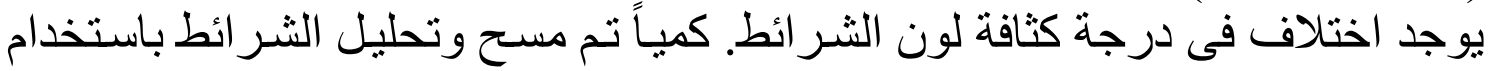

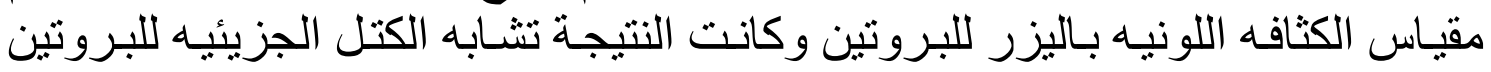

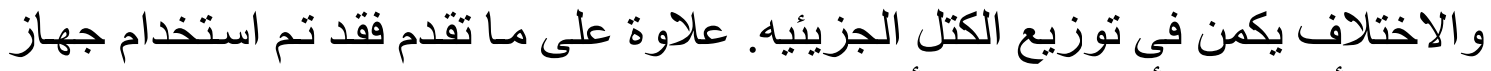

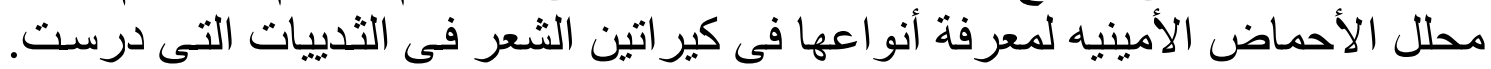

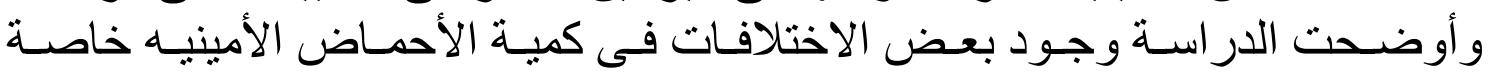
المثيونين و الأيزوليوسين و الليسين و الأرجنين. 